\title{
Restitution in the Criminal Process: Procedures for Fixing the Offender's Liability
}

The Victim and Witness Protection Act of $1982^{1}$ represents an ambitious attempt by Congress to bring restitution ideologically and practically to the fore in the federal criminal process. Despite the extended authority provided by the Act and the sweeping rhetoric accompanying it, ${ }^{2}$ however, there is reason to doubt whether the Act will accomplish its goal of "ensur[ing] that the Federal Government does all that is possible within limits of available resources to assist victims and witnesses of crime without

1. Pub. L. No. 97-291, 96 Stat. 1248 (1982). The new restitution provisions, $\S 5$ of the Act, 96 Stat. at 1253-55, are codified at 18 U.S.C. $\$ \S 3579-3580$ (1982). In addition to the restitution sections, the Act requires the preparation of a "Victim Impact Statement" in every federal criminal case, $\S 3,96$ Stat. at 1249 (codified as FED. R. CRIM. P. 32(c)(2)), strengthens criminal and civil protections of victims and witnesses against intimidation, $\S 4,96$ Stat. at 1249-53 (codified at 18 U.S.C. $\$ \S 1512-1515$ (1982)), and requires the Attorney General to develop guidelines for the fair treatment of crime victims and witnesses in the federal criminal justice system, $\S 6,96$ Stat. at 1256-57 (not codified). The Department of Justice issued guidelines in compliance with the Act on July 9, 1983. Guidelines for Victim and Witness Assistance, 48 Fed. Reg. 33,774 (1983).

2. In Congressional debate, the Act was heralded by its principal co-sponsors as legislation which "will do much to restore the faith of the American public in our system of justice," 128 CoNG. REC. S11,435 (daily ed. Sept. 14, 1982) (statement of Sen. Laxalt), and as a measure "to begin the process of rebalancing the scales of justice... [to] insure that victims are given at least the rights now afforded routinely to the accused," id. at S11,434 (statement of Sen. Heinz). Representative McCollum described restitution as "the ultimate justice," id. at H8207 (daily ed. Sept. 30, 1982); the Act would make restitution "the expected norm, and no longer an afterthought," id. at $\$ 13,063$ (daily ed. Oct. 1, 1982) (statement of Sen. Heinz).

Congress passed the Act with exceptional speed and bipartisan support. The Senate Judiciary Committee reported S. 2420 favorably on August 19, 1982. S. REP. No. 532, 97th Cong., 2d Sess. 1, reprinted in 1982 U.S. CODE CONG. \& AD. NEws 2515. The Senate considered and passed S. 2420 on September 14, 1982. 128 CoNG. Rec. S11,430-42 (daily ed. Sept. 14, 1982). On September 30, 1982, the House prematurely ended committee consideration of its version of the Act, H.R. 7191, and considered and passed the bill. Id. at H8201-15 (daily ed. Sept. 30, 1982). On October 1, 1982, the Senate passed the House version, but with further amendments of its own. Id. at \$13,056-64 (daily ed. Oct. 1, 1982). The House then approved this final version from the Senate. Id. at H8464-70 (daily ed. Oct. 1, 1982). President Reagan signed the Act into law on October 12, 1982, less than two months after it left committee in the Senate. Victim and Witness Protection Act of 1982, Pub. L. No. 97-291, 96 Stat. 1248, 1258 (1982). 
infringing on the constitutional rights of the defendant . . ."3 In adopting the statute, Congress failed to address an issue which is central to the balance of the interests of victims and the rights of defendants-the question of when in the criminal process the offender's liability to pay restitution should be fixed.

This Note examines that issue. The Note first describes the tension between defendants' rights and victims' interests in compensation which is created by linking the imposition of restitutionary liability to the technical conviction which emerges from the adjudicatory phase of the criminal process. ${ }^{4}$ The Note then examines two possible resolutions of this tension: moving the liability decision from the adjudicatory to the sentencing phase

3. Victim and Witness Protection Act of 1982, Pub. L. No. 97-291, $\S 2(b)(2), 96$ Stat. 1248, 1249 (1982).

The restitution sections of the Act have failed to pass constitutional muster in an early challenge. United States v. Welden, 568 F. Supp. 516, 534 (N.D. Ala. 1983) (Act's denial of jury trial on damages violates defendants' Seventh Amendment rights), appeal docketed, No. 83-7-444 (11th Cir. Aug. 8, 1983). The court also held the restitution provisions unconstitutional under the Fifth Amendment ("This is not 'fair'. This is not 'reasonable'. This is not 'due process'." Id. at 535.) and the Fourteenth Amendment ("The probability of disparate results . . . is so great . . . that it is impossible to look forward to enough equality of application for the Act to comply with 'equal protection'." Id.). The court did not go so far as to condemn as unconstitutional the longstanding practice of determining restitutionary liability without a jury under the probation statute, 18 U.S.C. $\S 3651$ (1982). 568 F. Supp. at 534.

Some commentators have maintained that restitutionary liability is a species of civil liability and that the criminal and civil processes are and should be conceptually and practically distinct. See Epstein, Crime and Tort: Old Wine in Old Botlles, in Assessing THE CRImINal: Restitution, RetRibution, and the Legal Process 231-57 (R. Barnett \& J. Hagel eds. 1977). But see People v. Heil, 79 Mich. App. 739, 748, 262 N.W.2d 895, 900 (1977) (criminal conviction does not necessarily establish civil liability, but civil liability not necessary to impose restitution as condition of probation); State v. Scherr, 9 Wis. 2d 418, 426, 101 N.W.2d 77, 81 (1960) (rejecting arguments based on "erroneous theory that determining the amount of restitution is a civil action to determine civil liability"). Epstein acknowledges, however, that there may be an overlap between the civil and criminal processes within which restitution is appropriate. Epstein, supra, at 255-257. In fact, this area of overlap includes all the cases to which restitution pertains-crimes which involve an identifiable, specific victim and which comprehend within their terms intentional torts. Within this area, a guilty verdict, because it includes a finding of intentional conduct surpassing any civil standard of negligence, is a proxy for the finding of restitutionary liability. See People v. Richards, 17 Cal. 3d 614, 620, 552 P.2d 97, 101, 131 Cal. Rptr. 537, 541 (1976) ("A judge may infer from a jury verdict of guilt in a theft case that a defendant is liable to the crime victim.").

Congress limited application of the Act to Title 18 and air piracy offenses, thus excluding criminal prosecutions under certain regulatory laws such as the antitrust and securities laws. 18 U.S.C. $\S 3579$ (a)(1) (1982). Similarly, courts have refused to award restitution in cases where issues of causation are complicated by divergence between the intent involved in the offense and the nature of the injury to the victim. See, e.g., People v. Williams, 247 Cal. App. 2d 394, 55 Cal. Rptr. 550 (1966) (disallowing condition requiring restitution of unpaid balance to credit card company when offense committed was assault by cardholder on merchant who refused to honor card); People v. Becker, 349 Mich. 476, 84 N.W.2d 833 (1957) (state cannot require driver convicted of leaving scene of accident to make restitution to pedestrians injured in accident); State v. Barnett, 110 Vt. 221, 3 A.2d 521 (1939) (same); cf. People v. Good, 287 Mich. 110, 282 N.W. 920 (1938) (upholding condition of restitution imposed on driver convicted of negligent homicide in death of pedestrian; discussed extensively in Becker).

4. The Note contrasts the "adjudicatory phase" with the "sentencing phase." The adjudicatory phase includes the events preceding and including the final disposition of all charges either in a plea of guilty or nolo contendere or in a verdict following a trial. 
or making an exception to the adjudicatory phase rule when the defendant admits to restitutionary liability broader than the scope of the conviction. From this examination, the Note concludes that restitutionary liability must be imposed in the adjudicatory phase but that a more comprehensive solution than the admissions exception is needed. The Note then refines the adjudicatory phase approach by proposing changes in the Federal Rules of Criminal Procedure which would integrate restitution into the pleading and plea bargaining stages of the criminal process.

\section{The Act And Its Policy}

Under prior federal law, ${ }^{b}$ a court could order restitution only as a condition of probation ${ }^{6}$ and only "to aggrieved parties for actual damages or loss caused by the offense for which conviction was had." The Act expands this authority dramatically by abolishing the probation limitation and by omitting-although without substantial comment ${ }^{8}$ - the restrictive "offense of conviction" provision." Federal courts now may order

5. Until passage of the Act, the authority to order restitution in federal cases was found in the federal probation statute, 18 U.S.C. $\$ 3651$ (1982). The Act did not repeal the portion of the probation statute relating to restitution, thus throwing into doubt whether probationary restitution continues to be governed by $\S 3651$. The Act militates against giving continuing effect to the old provision because the Act makes any restitution order entered by the sentencing court an automatic condition of any probation granted, 18 U.S.C. $\$ 3579(\mathrm{f})(2),(\mathrm{g})(1982)$, thus subsuming the former authority in the new provisions. Section 3651 remains available, however, as authority for ordering restitution in cases involving crimes excluded from the coverage of the Act. A. PARTRIDGe, A. Chaset \& W. ELDRIDGe, The Sentencing Options of Feneral District Judges 8 (rev. ed. 1983).

6. As in the federal statute, the probation limitation was common before approximately 1977 to almost all jurisdictions where the authority to order restitution existed. See, e.g., CaL. Penal Code $\S 1203.1$ (West Supp. 1983); Mich. Comp. Laws ANN. § 771.3 (West Supp. 1983); N.J. Stat. ANN. \$2A:168-2 (West 1972) (repealed 1979); see Goldstein, Defining the Role of the Victim in Criminal Prosecution, 52 Miss. L.J. 515, 521 (1982). Since 1977, many states have enacted sentencing reforms which, like the Act, release restitution from the limitations of probation. See, e.g., ALA. CODE $\$ \S 15-18-65$ to -77 (1982) (enacted 1980); ARIz. REv. STAT. ANN. § 13-603(C) (Supp. 1983) (enacted 1983); Fla. Stat. ANN. $\$ 775.089$ (West 1981) (enacted 1977); Ill. ANN. STAT. ch. 38, § 1005-5-6 (Smith-Hurd 1982) (enacted 1977); N.J. STAT. ANN. \$§ 2C:43-3, :44-2 (West 1982) (enacted 1979); UTAH Code ANN. \& 76-3-201 (Supp. 1983) (enacted 1979; amended 1981, 1983).

7. 18 U.S.C. $\S 3651$ (1982).

8. The statute itself is no more specific than to allow restitution "to any victim of the offense." 18 U.S.C. $\S 3579(a)(1)(1982)$. The legislative history of the Act contains no indication, other than citation of the language of the probation statute, S. REP. No. 532, supra note 2 , at 30 , reprinted in 1982 U.S. Code CoNG. \& AD. NEws at 2536, that Congress appreciated the importance of the specific language of the probation statute in determining how restitutionary liability is fixed. The legislative history also contains no discussion of the approach to restitution taken in states without "offense of conviction" provisions.

9. An "offense of conviction" provision requires that an order of restitution be based only on offenses for which criminal guilt has been formally and finally adjudicated. Several state statutes also contain such provisions. See, e.g., N.J. STAT. ANN. \$ 2C:43-3 (West 1982) (restitution "shall not exceed [victim's] loss"; "loss" defined as that "caused by the conduct constituting the offense by the offender"); UTAH CODE ANN. \$ 76-3-201(3)(a) (Supp. 1983) (restitution limited to "offense of which the defendant has pleaded guilty, is convicted, or ... any other criminal conduct admitted by the defendant to the sentencing court"). 


\author{
restitution "in addition to or in lieu of any other penalty authorized \\ by law."10
}

Two clear policies inform the use of restitution as a criminal sanction under the Act. First, the Act advances restitution as a means of reparation to victims ${ }^{11}$ rather than as a technique for rehabilitating offenders. ${ }^{12}$ This shift in focus ${ }^{13}$ changes the standards by which restitution should be measured. If the aim of restitution were rehabilitative, the amount of restitution ordered should be commensurate with the offender's ability ${ }^{14}$ and

10. 18 U.S.C. $\& 3579$ (a)(1) (1982). Under the Act, a restitution order stands as an independent component of the court's sentence and may be enforced by the United States or the victim "in the same manner as a judgment in a civil action:" Id. $\S 3579(\mathrm{~h})$. The court may order restitution to be paid immediately or in installments during a period of probation or during a period up to five years following the expiration of a term of imprisonment. Id. $\$ 3579(f)$. In addition, the Act provides that any restitution order automatically becomes a condition of any term of probation or parole the offender may serve as part of the court's sentence. $I d$. $\S 3579(\mathrm{~g})$. The offender may be subject to revocation of parole or probation for failure to comply with the order of restitution. Id.

11. The Senate Judiciary Committee stated the premise of the restitution sections to be: "[W]hatever else the sanctioning power of society does to punish its wrongdoers, it should also insure that the wrongdoer is required to the degree possible to restore the victim to his or her prior state of well-being." S. REP. No. 532, supra note 2, at 30, reprinted in 1982 U.S. CodE CoNG. \& AD. NEws at 2536. The Committee associated the Act with the "revived effort at producing restitutive justice" through "new methods at constructive, victim-oriented sentencing practices [that] can insure . . . that the prosecutorial, judicial and probation authorities know, and are encouraged to respond to, the victim's monetary damages." Id. at 31, reprinted in 1982 U.S. Cone CoNG. \& AD. NEws at 2537.

12. The act of making restitution-especially when made in kind or by personal service-provides the offender an opportunity for a cathartic recognition of wrongdoing and for symbolic expiation of guilt. Eglash, Creative Restitution: A Broader Meaning for an Old Term, 48 J. CRIM. L. CrImINoLOGY \& POLICE ScI. 619, 622 (1958); Schafer, Restitution to Victims of Crime-An Old Correctional Aim Modernized, 50 MinN. L. Rev. 243, 249-50 (1965).

13. Although the Act stresses the needs of victims, it does not reject entirely the rehabilitative potential of restitution. See 128 CoNG. Rec. H8201 (daily ed. Sept. 30, 1982) (statement of Rep. Rodino) (" One who successfully makes restitution should have a positive sense of having earned a fresh start and will have tangible evidence of his or her capacity to alter old behavior patterns and lead a law-abiding life." " (quoting Huggett v. State, 33 Wis. 2d 790, 798, 266 N.W.2d 403, 407 (1978))); S. REP. No. 532, supra note 2, at 32, reprinted in 1982 U.S. CoDE CoNG. \& AD. NEwS at 2538 (Act allows alternative forms of restitution so that restitution can "both satisfy the victim and provide maximum rehabilitative incentives to the offender").

The Act also does not endorse all of the radical implications of restitutionary justice. Advocates of the restitutionary theory of justice argue for a victim-oriented criminal law with restitution as its only legitimate remedial objective. See Barnett \& Hagel, Assessing the Criminal: Restitution, Retribution, and the Legal Process, in Assessing the Criminal: Restitution, Retribution, ANd the Legal PROCEss, supra note 3, at 1 . Restitutionary justice de-emphasizes the violation of social norms in the crime and focuses instead on the exchange between two individuals. Id. at 10. A crime produces an imbalance of rights between the offender and the victim, and justice is served only when the transaction is reversed by the act of restitution. 1d. at 11, 26-27.

The premise of the Act is procedurally conservative, requiring that the basic principles of victimoriented restitution be served without "unduly complicat[ing] or prolong[ing] the sentencing process." 18 U.S.C. § 3579 (d) (1982). The Act does not challenge the prosecutorial hegemony of the state by affording a formal prosecutorial role to the victim. But see Barnett \& Hagel, supra, at 12, 26 (restitutionary justice implies absolute control of prosecution by victim). Nor does the Act establish restitution as the exclusive criminal sanction. But $c f$. id. at 17-18, 24-25 (punitive or deterrent goals may be served by restitution incidentally, but they cannot be legitimate ends of restitutionary justice system accomplished by other types of sanctions).

14. The ability of the offender to pay restitution remains a factor to be considered by the sentencing court under the Act. 18 U.S.C. $\S 3580$ (a) (1982). Such a provision is necessary to avoid the 
willingness ${ }^{15}$ to pay; it need not even approximately compensate the victim. In contrast, reparative restitution is measured strictly by the extent of the victim's injury. ${ }^{16}$ To be just, the amount of restitution must compensate the victim exactly. ${ }^{17}$

The second policy clearly articulated in the Act is that restitution should be a priority of the criminal justice system. ${ }^{18}$ Reparative restitution is to come before the government's interest in punishing or even rehabilitating the offender. ${ }^{10}$ Thus, the Act not only frees restitution from the confines of probation but also elevates restitution to a status equal to or above that held by the traditional punitive sanctions of imprisonment and fines.

Unlike the policies of the Act, the procedures adopted by Congress to advance restitution are unclear because of the ambiguous intent of Congress in omitting the "offense of conviction" language from the new statute. Under the former statute, the "offense of conviction" provision linked restitution to the technical offense of conviction; the final dismissal of a

constitutional defect produced when imprisonment results from the mere inability to pay restitution. See Bearden v. Georgia, 103 S. Ct. 2064, 2073-74 (1983) (revocation of probation for failure to pay fine and restitution reversed where court made no finding of lack of good faith effort by defendant to pay amounts).

15. The offender's initiative is an important part of restitution's rehabilitative mission. See Eglash, supra note 12, at 619,620-21 (distinguishing "creative restitution" from reparation or indemnification: restitution is necessarily voluntary while reparation and indemnification are compulsory and lack restitution's rehabilitative potential).

16. See Barnett \& Hagel, supra note 13, at 26-27. The theoretical justification for the measure of damages is a separate issue from the question of what types of injuries will be compensated in any particular system of restitution. The Act authorizes only certain types of damage awards to victims of property offenses, 18 U.S.C. § 3579 (b)(1) (1982), to victims who are injured physically, id. \$ 3579 (b)(2), and to the estate of victims who are killed, id. \$ 3579(b)(3).

Congress restricted the Act to restitution orders where imposing restitution "will not unduly complicate or prolong the sentencing process," id. \$ 3579(d), recognizing that the provision would exclude from criminal restitution certain damages which could still be awarded in a civil action, 128 CoNG. REC. H8207 (daily ed. Sept. 30, 1982) (statement of Rep. McCollum). Congress decided that criminal restitution should be limited to the victim's readily identifiable expenses and should not be extended to include damages which are difficult to calculate, such as pain and suffering. See id. The original Senate bill authorized recovery of lost income in the case of both homicide and physical injury not resulting in death, S. 2420, 97th Cong., 2d Sess. \$ 301(a), 128 Cong. REC. S11,430, S11,432 (daily ed. Sept. 14, 1982), but the version ultimately passed allows recovery only of income lost as a consequence of an injury, 18 U.S.C. $\S 3579$ (b)(2) (1982). See also People v. Heil, 79 Mich. App. 739, 748-49, 262 N.W.2d 895, 900 (1977) ("[R]estitution for personal injury . . . generally should be more limited in scope than civil damages. . . . [R]estitution should encompass only those losses which are easily ascertained and measured, and which are a direct result of the defendant's criminal acts.").

17. Restitutionary justice places a premium on the fullness and exactness of restitution. Just as incomplete compensation does not remedy fully the wrong committed, overcompensating the victim is an injustice against the offender. Barnett \& Hagel, supra note 13, at 13.

18. This priority is written into the Act in the requirement that the sentencing court state reasons on the record if it does not order restitution or orders only partial restitution. 18 U.S.C. $\$ 3579$ (a)(2) (1982). See also 128 Cong. Rec. S13,064 (daily ed. Oct. 1, 1982) (statement of Sen. Laxalt) ("It is the intent of Congress that judges order restitution in each and every case where the court finds there has been property loss or injury to the victim.").

19. See supra note 11 (statement of Senate Judiciary Committee). 
charge before sentencing eliminated that charge as the basis for restitutionary liability. ${ }^{20}$ Defendants developed specific expectations regarding their exposure for restitution based on the outcome of the adjudicatory phase. ${ }^{21}$ The "offense of conviction" clause protected these expectations and thus enabled defendants to plan their defense strategies before pleading based on their estimates of their potential restitutionary liability.

At the same time, the "offense of conviction" regime threatened the effectiveness of restitution in providing complete compensation to victims ${ }^{\mathbf{3 2}}$ because the technical offense of conviction frequently fails to include the full scope of the offender's conduct. ${ }^{23}$ This potential underinclusiveness springs from two sources. First, compared to the finding of liability in a collateral civil suit, a criminal conviction may be narrower because the procedural rules-particularly evidentiary rules and the standard of proof-are stricter in criminal law. Second, criminal convictions often do not include aspects of the defendant's actual conduct, either because of a prosecutorial decision not to charge a particular aspect of the offense or because of a reduction or dismissal of counts in plea negotiations.

There are important distinctions between these two kinds of underinclusiveness. The second type of underinclusiveness is both more drastic ${ }^{24}$

20. In Karrell v. United States, 181 F.2d 981 (9th Cir.), cert. denied, 340 U.S. 891 (1950), the defendant was charged with seventeen counts of filing false statements on veterans' loan guarantees. She was convicted on six counts and acquitted of two; nine counts were dismissed. The sentencing court conditioned probation on payment of restitution to all seventeen victims named in the indictment and to one other victim not named. The Ninth Circuit Court of Appeals modified the sentence, holding that the restitution condition could stand only as to the six counts of conviction. See United States v. Follette, 32 F. Supp. 953, 955 (E.D. Pa. 1940) (restitution condition limited to amount of loss stated in indictment on which conviction was had); see also United States v. Johnson, 700 F.2d 699, 701 (11th Cir. 1983) (per curiam) (in multicount indictment, restitution restricted to counts of conviction); United States v. Orr, 691 F.2d 431, 433 (9th Cir. 1982) (Karrell/Folletle principle is federal majority rule); United States v. Buechler, 557 F.2d 1002, 1008 (3d Cir. 1977) (following strict rule of Follette).

21. United States v. Orr, 691 F.2d 431, 432 (9th Cir. 1982) (defendant believed restitution could not exceed amount in superseding indictment); see also State v. Bausch, 83 N.J. 425, 437, 416 A.2d 833,840 (1980) ("Defendant reasonably believed that pursuant to the plea bargain and dismissal of Count 3, the embezzlements were out of the case. Requiring restitution ... under Count 3 ... would be manifestly unjust .....").

22. In United States v. McLaughlin, 512 F. Supp. 907 (D. Md. 1981), Judge Miller acknowledged that his restitution order exceeded the limits of the offense of conviction, but he defended the order on the basis of public policy:

The court believes [a technical reading of the former statute invalidating the broad restitution condition] to be unwarranted as it would be contrary to the goals of probation and would have significant practical ramifications for both society and defendants.

[T]o permit a defendant who freely admits his or her guilt, and the amount of loss caused thereby, to avoid making the aggrieved party at least economically whole is intolerable from a societal perspective.

Id. at 912 .

23. Goldstein, supra note 6 , at 537.

24. Discretionary charging and plea bargaining eliminate whole aspects of the offense. Where an offender has committed a series of discrete offenses against multiple victims, dismissal or failure to charge some of the offenses will exclude certain victims from any recovery. If the offender has committed multiple offenses against a single victim-for example, a burglary causing property damage and a 
and less justified than the first kind of underinclusiveness because it is grounded upon expediency unrelated to the victim's interest in recovering reparations. ${ }^{25}$ These arbitrary exclusions under the former statute left victims with little or no compensation, despite the conviction of the offender on related charges and despite the willingness of the sentencing court to compensate the victim. ${ }^{26}$

Courts thus face a dilemma in interpreting the Act. If courts abolish the connection between the precise offense of conviction and the restitution order, they will expose defendants to restitutionary liability bearing no relation to the expectations which guided the defendants' defense strategies. The adjudicatory phase would have little meaning in the sentencing phase. But to perpetuate an unmodified "offense of conviction" constraint will undercut the Act's intent to compensate victims as completely as possible. An interpretation of the Act is needed which preserves the function of the adjudicatory phase in defining the liability of the defendant while still permitting comprehensive responses to the injuries of victims.

\section{The Gase Law as Experimentation}

In balancing the right of defendants against the right of victims, federal courts interpreting the Act may draw on the experience of federal and state courts in implementing other restitution statutes. The case law reveals two distinct approaches to resolving the tension between the interests of victims and offenders, each approach based on a different kind of statute. ${ }^{27}$ Both approaches strike unsatisfactory balances.

subsequent assault resulting in physical injury-the failure to prosecute either charge to conviction will limit the victim to partial recovery.

Compared with these exclusions, the effects of variations between the civil and criminal processes on the scope of liability are more difficult to gauge. Although prosecutors must contend with stricter procedural rules, they benefit from such features as extensive police resources for investigation and the pressures on criminal defendants to plea bargain to avoid potentially severe sanctions.

25. Underinclusiveness associated with the strictness of rules of criminal procedure relative to civil rules is an unavoidable consequence of the principle that the seriousness of criminal guilt and sanctions warrants extraordinary procedural safeguards. Any attempt to relax procedural rules in the criminal process to address this source of underinclusiveness will produce tension with this fundamental principle. By stating that the Act's solicitude to victims' interests is qualified by the need to avoid infringing defendants' rights, supra pp. 505-06, Congress resolved any such tensions in favor of preserving procedural protections in the criminal process.

26. There is no reason to believe, for example, that in Karrell v. United States, 181 F.2d 981 (9th Cir.), cert. denied, 340 U.S. 891 (1950), the government's case as to any one of the seventeen victims named in the indictment was significantly stronger than its case with respect to any other victim; yet because eleven counts were dismissed, only six of the seventeen victims were awarded restitution. The case similarly does not explain why charges were not brought with respect to an eighteenth victim, who also received no restitution.

27. For comparative discussions of various state statutes, see People v. Williams, 247 Cal. App. 2d 394, 404-09, 55 Cal. Rptr. 550, 557-60 (1966); People v. Gallagher, 55 Mich. App. 613, 617-19, 223 N.W.2d 92, 95 (1974), leave denied, 393 Mich. 766 (1974); State v. Bausch, 171 N.J. Super. 314, 319-21, 408 A.2d 1085, 1087-88 (App. Div. 1979), modified, 83 N.J. 425, 416 A.2d 833 (1980). 


\section{A. Shifting the Liability Decision: The Sentencing Phase Approach}

In states without specific "offense of conviction" provisions, ${ }^{28}$ the court can fix a defendant's restitutionary liability in the sentencing phase without being bound by the outcome of the adjudicatory phase. 29 This approach attempts to address both sources of underinclusiveness. First, the court is free to apply more liberal evidentiary rules in the sentencing phase $^{30}$ and to fashion a special standard of proof to govern the transplanted determination of liability. ${ }^{31}$ Second, because the court's determination is de novo, it is, at least in theory, not restricted by the technical offense of conviction. The court may consider charges that have been excluded from the indictment or dismissed in a plea agreement. In some cases, the court can even effectively re-try the defendant on charges of which he was acquitted at trial..$^{32}$

The courts of these "nonrestrictive" states most often justify this authority by asserting that probation is a matter of grace, not of right. ${ }^{33}$ The

28. For examples of nonrestrictive state statutes, see ARIz. REv. STAT. ANN. $\S 13-603$ (C) (Supp. 1983) ("restitution . . . in such an amount and manner as the court may order"); CAL. PENAL CodE $\S 1203.1$ (West Supp. 1983) (probation conditions must be "reasonable" and "fitting and proper to the end that justice may be done [and] that amends may be made . . . for any injury . . . resulting from ... [the] breach [of the law]"); IL.L. ANN. STAT. ch. 38, § 1005-5-6(b) (Smith-Hurd 1982) ("Ir]estitution .... not to exceed the actual out of pocket expenses or loss to the victim proximately caused by the conduct of the defendant"); Mich. Comp. Laws ANN. $\S 771.3(2)$ (d) (West Supp. 1983) ("restitution to the victim"); WIS. STAT. ANN. $\$ 973.09(1 \mathrm{~m})(\mathrm{a}),(8)(\mathrm{a})$ (West Supp. 1983) ("not in excess of the pecuniary loss caused by the offense"; "pecuniary loss" defined as "damages . . . arising out of the facts or events constituting the probationer's criminal activities").

29. See, e.g., People v. Lent, 15 Cal. 3d 481, 487, 541 P.2d 545, 549, 124 Cal. Rptr. 905, 909 (1975) (allowing restitution condition based on count on which defendant was acquitted after trial because "additional circumstances were developed in the unusually prolonged probation hearing"); People v. Seda-Ruiz, 87 Mich. App. 100, 103-04, 273 N.W.2d 602, 604 (1978) (per curiam) (quoting transcript of inadequate sentencing hearing; remanded for further hearing on liability for bad checks not included in offense of conviction).

30. Williams v. New York, 337 U.S. 241, 246-47 (1949).

31. See, e.g., People v. Pettit, 88 Mich. App. 203, 207, 276 N.W.2d 878, 881 (1979) ("persuasive support in the record"); State v. Harris, 70 N.J. 586, 599, 362 A.2d 32, 38-39 (1976) ("factual basis" in New Jersey; discussing other state statutes).

32. People v. Lent, 15 Cal. 3d 481, 541 P.2d 545, 124 Cal. Rptr. 905 (1975); cf. People v. Richards, 17 Cal. 3d 614, 552 P.2d 97, 131 Cal. Rptr. 537 (1976) (restitution condition following acquittal not allowed; Lent distinguished as involving extraordinary sentencing hearing). Contra People v. Winquest, 115 Mich. App. 215, 320 N.W.2d 346 (1982) (restitution cannot be based on crime for which defendant was tried and acquitted).

33. See People v. Williams, 247 Cal. App. 2d 394, 399-400, 403-04, 55 Cal. Rptr. 550, 554, 556-57 (1966); People v. Gallagher, 55 Mich. App. 613, 620, 223 N.W.2d 92, 96 (1974), leave denied, 393 Mich. 766 (1974).

The Supreme Court has described probation as "a period of grace [granted] in order to aid the rehabilitation of a penitent offender." Burns v. United States, 287 U.S. 216, 220 (1932). "Probation is thus conferred as a privilege and cannot be demanded as a right." Id. Lower federal courts have not applied the grace rationale in conditioning probation on restitution, however, because the restitution authority derived from a specific provision of the probation statute, 18 U.S.C. $\S 3651$ (1982). See United States v. Follette, 32 F. Supp. 953, 954 (E.D. Pa. 1940) ("I think it clear that this general language is limited by the later specific provision so far as restitution is concerned."). But see United States v. McMichael, 699 F.2d 193, 195 (4th Cir. 1983) (reading general opening sentence of $\$ 3651$ as broadening more specific restitution phrase of statute). 
defendant, in this view, voluntarily accepts the offered terms of probation in a kind of contract with the state. He is free to opt for the imposition of a non-probationary sentence if he feels the conditions are excessive or too onerous. ${ }^{34}$

This rationale is inadequate for the purposes of the Act for three reasons. First, its basic premise is faulty. The defendant, faced with probable imprisonment and with a judge who may react severely to his rejection of the court's offer of leniency, is unlikely to reject probation except to avoid the most extreme conditions. ${ }^{35}$ Second, even if the defendant's choice were a real one, leaving the victim's recovery to the option of the offender is antithetical to the use of restitution to serve the needs of victims. ${ }^{38}$ Third, the grace rationale allows only for probationary restitution. A more coherent rationale is needed once restitution is removed from the courts' traditionally expansive probationary authority.

Like the probationary approach founded on the grace rationale, "real offense" sentencing creates a secondary liability decision in the sentencing phase, but "real offense" sentencing applies beyond the context of probation. ${ }^{37}$ Under this approach, the sentencing judge may draw informal conclusions about what constitutes the "real offense" committed by the defendant, without regard to the technical offense found by formal conviction..$^{38}$ The sentence imposed reflects the severity of this "real offense," thus correcting for the potentially incomplete or arbitrary results of the adjudica-

34. See People v. Cummings, 120 Ariz. 69, 71, 583 P.2d 1389, 1391 (Ct. App. 1978); People v. Good, 287 Mich. 110, 115-16, 282 N.W. 920, 923 (1938).

35. See People v. Richards, 17 Cal. 3d 614, 619, 552 P.2d 97, 100, 131 Cal. Rptr. 537, 540 (1976) ("defendant is in effect required to choose between accepting incarceration and righting a wrong he may not in fact have committed"); People v. Becker, 349 Mich. 476, 482, 84 N.W.2d 833, 836 (1957) (to say defendant has a choice "begs the question" because not every alternative is lawful); State v. Reedeker, 534 P.2d 1240, 1241 (Utah 1975) (sentence is "akin to an alternative to pay up something not found in the record or be imprisoned for debt").

36. Leaving restitution to the willingness of the defendant to accept it as a condition of probation is analogous to giving the prosecutor and defendant absolute power over whether to include restitution in plea agreements. See infra note 50.

37. L. Wilkins, J. Kress, D. Gottrredson, J. Galpin \& A. Gelman, Sentencing GuideInNEs: Structuring Judicial. Discretion 26-27 (1978); Tonry, Real Offense Sentencing: The Model Sentencing and Corrections Act, 72 J. CRIM. L. \& CRMmology 1550, 1561-80 (1981) (criticizing real offense sentencing as attempt to sidestep substantive criminal law and procedural protections of the adjudicatory phase).

38. United States v. Grayson, 438 U.S. 41 (1978) (sentencing judge may consider defendant's false testimony at trial in imposing sentence); Williams v. New York, 337 U.S. 241 (1949) (sentencing judge may consider information concerning unadjudicated crimes not admissible at trial).

A variation of "real offense" sentencing exists in the decisionmaking authority of the United States Parole Commission. In determining the period of incarceration an offender should serve before release on parole, the Commission rates the severity of the offense based on information from various sources, including the pre-sentence investigation report. 28 C.F.R. $\$ 2.19$ (c) (1982). The Commission resolves disputes by the preponderance of the evidence standard, and it may "consider in any determination, charges upon which a prisoner was found not guilty after trial [if] reliable information is presented that was not introduced into evidence at such trial (e.g., a subsequent admission or other clear indication of guilt)." Id. 
tory phase. The technical offense of conviction does, however, still determine the maximum sentence that the court may impose. ${ }^{38}$ Through this link, the expectations of punishment which guide the defendant in pleading and in preparing his defense are protected from uncontrolled expansion at the time of sentencing. ${ }^{40}$

Real offense sentencing fails, however, when applied to restitution. The amount of restitution is directly related to the offense causing injury to a victim, ${ }^{11}$ and therefore the entire offense is needed as a basis for a restitution order which will compensate the victim for the entire injury suffered. By comparison, real offense sentencing rests on the premise that conviction of only a part of the "real offense" can establish exposure to a quantum of punitive sanctions considered to reflect adequately the severity of the entire "real offense." 42 This premise cannot be reconciled with the logical framework of restitution, in which the offense and liability are linked to the amount of restitution ultimately ordered. ${ }^{33}$ Real offense sentencing therefore is not an answer to the underinclusiveness of the technical offense of conviction.

\section{B. The "Offense of Conviction" Response: Informal Bargaining for Restitution}

In other jurisdictions, the existence of statutory "offense of conviction" provisions has forced courts to confront more directly the tension between defendants' need for protection of their expectations regarding restitution and the need to obtain restitution awards which cover the full scope of the offense committed. These courts have recognized that the strictest reading of the "offense of conviction" provision would lead to a procedural re-

39. "A sentencing judge, however, is not confined to the narrow issue of guilt. His task urithin fixed statutory or constitutional limits is to determine the type and extent of punishment after the issue of guilt has been determined." Williams v. New York, 337 U.S. 241, 247 (1949) (cmphasis added).

40. For example, consider a defendant charged with five counts of an offense carrying a statutory maximum penalty of five years imprisonment and/or a $\$ 10,000$ fine. In total, the defendant faces the possibility of 25 years in prison and a $\$ 50,000$ fine. If he is convicted of just two of the counts, real offense sentencing holds that he may be sentenced on the basis of the judge's view that he in fact committed all five offenses, but because there are just two formal counts of conviction, he may be sentenced to no more than 10 years in prison and a $\$ 20,000$ fine.

41. Each count of an indictment carries its own quantum of restitution depending on the facts of the offense alleged in the count.

42. Real offense sentencing is effective only if the statutory maximum sentence prescribed by the legislature for any given offense is higher than the normal sentence given for that offense alone. Thus, in a system of mandatory sentences, real offense sentencing would fail because the state could never build up, on the basis of a few counts, a margin of exposure within which to vary the exact sentence imposed.

43. To demonstrate this failure, consider the hypothetical situation described in note 40 , supra, with the additional loss of $\$ 1000$ to a victim associated with each of the five counts. Once the offense of conviction is pared down to just two counts, the basis for restitution of the full $\$ 5000$ in actual damages is irretrievably lost. The amount of restitution could not exceed $\$ 2000$. 
quirement of prospective notice to the defendant of his liability for a specific amount of restitution if he were convicted of the count as alleged. ${ }^{44}$ At the same time, courts have seen that such a rigid requirement would cripple the effectiveness of restitution as a means of compensating victims. ${ }^{45}$ Confronted with this dilemma, the "offense of conviction" courts have sought to increase the flexibility of the rule rather than to impose a rigid requirement of binding advance notice. ${ }^{48}$

The most common approach in "offense of conviction" jurisdictions has been to fashion an exception to the rule when the defendant admits his obligation to make restitution. ${ }^{47}$ The admissions exception in effect creates an intermediate level of pleading where the defendant can concede his restitutionary liability without formally confessing criminal guilt. The scope of admitted restitutionary liability thus can be broader than the criminal liability represented by the offense of conviction. ${ }^{48}$ The most important consequence of the admissions exception is that it allows for the insertion of restitution into the plea bargaining calculus. In return for the

44. In United States v. Follette, 32 F. Supp. 953 (E.D. Pa. 1940), the court held that the specification in the indictment of an amount of alleged embezzlement placed an upper bound on the restitution condition imposed. In arriving at this holding, Judge Maris analogized the restitution limitation to the requirement that a sentencing court stay within the statutory maximum when imposing a fine. Id. at 955 . By simple extension, the analogy contemplates a requirement that the indictment include prospective, quantified notice to the defendant of his exposure to restitution.

45. See supra note 22.

46. United States v. Taylor, 305 F.2d 183 (4th Cir.), cert. denied, 371 U.S. 894 (1962), although a confused and sometimes contradictory opinion, is a pivotal case in the movement toward flexibility and away from the strict "offense of conviction" rule. Taylor was convicted on all counts of two indictments charging tax evasion and failure to file tax returns. The sentencing court imposed a restitution condition covering tax liabilities for periods not included in the indictments. Although the Fourth Circuit panel expressed its "substantial agreement" with United States v. Follette, 32 F. Supp. 953 (E.D. Pa. 1940), and United States v. Karrell, 181 F.2d 981 (9th Cir.), cert. denied, 340 U.S. 891 (1950), in striking down the broad restitution condition, it instructed the district court that on remand it could "properly require, as a condition of probation, payment of those taxes reported by the defendant as due for [years not included in the indictment] since such liability is admitted . . . ." 305 F.2d at 187.

47. In United States v. McLaughlin, 512 F. Supp. 907 (D. Md. 1981), the court cited three factors supporting its authority to condition probation on full restitution:

(1) the amount of loss suffered by an identifiable aggrieved party is certain; (2) the defendant admits, and there is no factual question as to whether, the defendant caused or was responsible

for the aggrieved party's loss; and (3) the defendant consents, freely and voluntarily, to make

full restitution and that it be a condition of probation.

512 F. Supp. at 908; see also Phillips v. United States, 679 F.2d 192, 194-95 (9th Cir. 1982) (quoting from and endorsing McLaughlin).

In some "offense of conviction" states, the admissions exception has been codified. See, e.g., ALA. Code § 15-18-66(1) (1982); Utah Code Ann. § 76-3-201(3)(a) (Supp. 1983).

48. In a few unusual cases, federal courts have upheld restitution conditions reaching beyond the scope of the offense of conviction or even beyond the limits of the indietment, even though the defendant did not agree to the extensions of liability. See United States v. Davies, 683 F.2d 1052, 1053-54 (7th Cir. 1982) (negotiated guilty plea to two counts of multicount, multidefendant indictment; defendant and prosecutor "agreed to disagree on the amount" of restitution; condition included amount in excess of offense of conviction); United States v. Roberts, 619 F.2d 1, 1-2 (7th Cir. 1979) (conviction on all counts of indictment involving fifty victims; restitution condition imposed encompassed full $\$ 1.7$ million scheme and over 34,000 victims). 
defendant's admission to restitutionary liability that is broader than the potential liability under the offense of conviction, the prosecutor can reduce the defendant's exposure to punitive sanctions by accepting a guilty plea to fewer counts of the indictment.

The chief shortcoming of the existing admissions exception is its lack of structure. Under the current system, the defendant's admission may be intentional or unintentional and may occur at any point in the criminal process. ${ }^{49}$ Ironically, the very bargaining process spawned by the admissions exception as part of the response to the rigidity of the "offense of conviction" rule itself requires strict enforcement of that limitation. Defendants and prosecutors will bargain for restitution only if there exists a structure which ensures each side the benefit of its bargain. What is lacking is a way for the defendant to plead his restitutionary liability formally so that the terms of, and compliance with, the bargain are established conclusively. ${ }^{50}$

\section{The Proposal}

The restitution case law shows the need to develop the law in conjunction with the Act on two levels. On a fundamental level, the experience of state courts not restricted by "offense of conviction" provisions demon-

49. United States v. McMichael, 699 F.2d 193, 194 (4th Cir. 1983) (amount agreed to during recess in sentencing hearing); United States v. Orr, 691 F.2d 431, 432 (9th Cir. 1982) (reversing condition based on alleged admission included in presentence report); United States v. Landay, 513 F.2d 306, 307 (5th Cir. 1975) (admission found in civil consent judgment between victim bank and defendant after date of pleading); United States v. McLaughlin, 512 F. Supp. 907, 908 (D. Md. 1981) (admission as part of plea agreement); see also State v. Bausch, 83 N.J. 425, 430, 416 A.2d 833,836 (1980) (admission found in statement made to police before prosecution was begun).

50. Recent cases provide the first appellate review of attempts to use restitution strategically in plea bargaining. In the Ninth Circuit, the mutuality of the bargain determines whether the "offense of conviction" limitation will be applied strictly. Compare Phillips v. United States, 679 F.2d 192 (9th Cir. 1982) (defendant's agreement that scope of guilty plea will not limit restitution in effect waives application of "offense of conviction" rule) with United States v. Orr, 691 F.2d 431 (9th Cir. 1982) (distinguishing Phillips because here defendant did not agree to restitution and applying "offense of conviction" rule strictly). In Orr, strict application of the "offense of conviction" provision reduced the amount of restitution from $\$ 3715$ to $\$ 200$, an effect the defendant apparently planned when she got the agreement of the prosecutor to file a superseding indictment much narrower than the original indictment. 691 F.2d at 432.

The Second Circuit has not looked as kindly on defendants' attempts to limit their liability through plea agreements. In United States v. Tiler, 602 F.2d 30 (2d Cir. 1979), the defendants attempted unsuccessfully to obtain a promise from the judge that the amount of restitution would be limited to $\$ 100,000$. When restitution in excess of $\$ 2.5$ million was ordered, they argued that they should be allowed to withdraw their guilty pleas. The court rejected this argument, holding that their expectation of limited restitution was unreasonable. Id. at 35.

The New Jersey Supreme Court looked more sympathetically on the defendant's strategic pleading in State v. Bausch, 83 N.J. 425, 416 A.2d 833 (1980). Bausch claimed that he pleaded guilty to two charges of breaking and entering to gain dismissal of a third embezzlement charge because the embezzlement count carried the possibility of a much greater amount of restitution. Id. at 429-30, 416 A.2d at 833 . The court accepted the argument, persuaded by the fact that the breaking and entering charges were high misdemeanors (felonies) while the embezzlement count was only a misdemeanor, and invalidated the restitution condition covering all three charges. Id. at 437,416 A.2d at 840 . 


\section{Griminal Restitution}

strates the need for some version of the "offense of conviction" link to the adjudicatory phase. When courts impose restitutionary liability during the sentencing phase-whether according to the grace rationale of probation or "real offense" sentencing-defendants are not adequately protected against restitution orders reaching arbitrarily and unexpectedly beyond the scope of the conviction found formally in the adjudicatory phase. On a more particular level, courts' experience with "offense of conviction" statutes shows the need to refine the procedural structure of the adjudicatory phase to establish a basis for more comprehensive restitution orders.

Legislative reform is not necessary to maintain the "offense of conviction" limitation; the restriction is consonant with the legislative history and policies of the Act and can be supplied by judicial construction. ${ }^{\mathbf{3 1}}$ Because of its role in protecting defendants' rights, an "offense of conviction" rule is supported-even dictated-by the general policy of the Act that the victims' interests should not be promoted to the detriment of the rights of defendants. Furthermore, locating the liability decision in the adjudicatory phase advances restitution as a priority of the criminal justice system. Imposition of restitutionary liability during the adjudicatory phase-the same time that the court determines liability for punitive sanctions-creates a parallel procedural structure which lends legitimacy and coherence to restitution as a sanction. Restitutionary liability fixed at the time of sentencing is precisely the "afterthought" that Congress condemned when it enacted the legislation. ${ }^{52}$ Making restitution a concern in the adjudicatory phase as well as at the time of sentencing will force judges, prosecutors, and defense counsel to consider the importance of restitution throughout the criminal process.

Preserving the "offense of conviction" rule locates the imposition of restitutionary liability in the adjudicatory phase generally. The imposition of restitutionary liability must be integrated specifically into a defendant's pleading. Congress or the Court should therefore amend Rule 11 of the Federal Rules of Criminal Procedure, the rule governing pleading hearings, in four ways.

51. "Although the language of the new statute is not identical to that of the probation statute, these precedents [cases interpreting the "offense of conviction" language of 18 U.S.C. $\$ 3651$ (1982)] may have relevance for the new law as well as the old." A. Partridge, A. Chaset \& W. Eldridge, supra note 5 , at 9 .

52. The Senate Judiciary Committee deplored the fact that "federal criminal courts have gone the way of their state counterparts, reducing restitution from being an inevitable if not exclusive sanction to being an occasional afterthought." S. REP. No. 532, supra note 2, at 30, reprinted in 1982 U.S. Code Cong. \& AD. News at 2536. 


\section{A. Amendments to the Federal Rules}

First, Congress should require the court to notify the defendant in open court, before he enters a plea, that the court may order restitution for any count of the indictment that results in a conviction or formal admission of liability. ${ }^{53}$ This basic notice requirement applies to restitution the same procedures as are now required for fines and imprisonment. ${ }^{54}$ Unlike the notice requirement for punitive sanctions, however, the amendment would not require that the notice include a quantified upper bound on the potential amount of restitution. Nor would it require that the prosecutor allege in the indictment the amount of loss caused by the offense. Specific notice is unnecessary because the factual description contained in the indictment provides the defendant with adequate notice of both the nature and the magnitude of the alleged injury. ${ }^{\mathrm{BS}} \mathrm{A}$ specific notice requirement might unduly restrict restitution orders because ascertaining the exact amount of loss often requires factual development which only rarely will have been completed before the defendant enters his plea.

A second revision to Rule 11 would authorize the court to accept a plea of guilty with the binding condition that the only sanction to be imposed on that count will be restitution. ${ }^{\text {s8 }}$ This plea of "guilty for restitution"

53. Rule 11(c) of the Federal Rules of Criminal Procedure should be amended by adding the following italicized provisions:

Rule 11. Pleas

$\cdots \cdot$

(c) Advice to Defendant

Before accepting a plea of guilty or nolo contendere, the court must address the defendant personally in open court and inform him of, and determine that he understands, the following:

(1) the nature of the charge to which the plea is offered, the mandatory minimum penalty provided by law, if any, and the maximum possible penalty provided by law, including the effect of any special parole term; and

(2) that he may be required to pay restitution to the victim or victims of any offense to which he pleads guilty or nolo contendere; and ....

54. FED. R. CRIM. P. 11(c)(1); see also Department of Justice, Implementation of Restitution Provisions of Victim-Witness Protection Act of 1982, at 16 (unpublished internal policy statement) ("The position of the Department of Justice is that a statement by the court that full restitution may be ordered should be added to the information provided to a defendant under Rule 11.").

55. An upper bound on the amount of restitution is built into this factual description because the court has no discretion in determining the amount of damages flowing from a particular act. See People v. Heil, 79 Mich. App. 739, 748, 262 N.W.2d 895, 900 (1977) (holding restitution condition "essentially arbitrary" when amount not based directly on victim's loss).

If the factual description of the offense contained in the indictment provides insufficient notice, the defendant may request a bill of particulars. Fed. R. CRIM. P. 7(f); 1 C. Wright, Federal PracTice ANd Procedure: CRiminal. 2d $\S 130$ (1982).

56. Rule 11(c)(1) of the Federal Rules of Criminal Procedure should be amended by adding the following italicized provisions:

Rule 11. Pleas

•.

(e) Plea Agreement Procedure

(1) IN General. The attorney for the government and the attorney for the defendant or the defendant when acting pro se may engage in discussions with a view toward reaching an agreement that, upon the entering of a plea of guilty or nolo contendere to 
would be similar to the admission of restitutionary liability currently cognizable in less formal terms under the admissions exception. ${ }^{67}$ The amendment would create a mechanism for formally incorporating restitution into the bargaining process. Under this provision, the court could impose traditional sanctions on only a few counts of an indictment while preserving the integrity of the entire indictment for the purposes of restitution. ${ }^{58}$

To counter the danger that restitution will be treated as merely another element to be raised or lowered in plea negotiations, a third amendment would require the court, before dismissing any count pursuant to a plea agreement, to inquire whether any potential restitutionary liability attaches to the count. ${ }^{39}$ To acquiesce in a dismissal, the court would have to

a charged offense or to a lesser or related offense, the attorney for the government will do any of the following:

(A) with leave of the court as provided in subsection (e)(3) of this rule, move for dismissal of other charges; or

(B) make a recommendation that restitution will be the only sanction imposed on a particular charge, with the understanding that upon acceptance of the plea agreement by the court such recommendation shall be binding upon the courl; or

(C) [current subsection (B)]; or

(D) [current subsection (C)].

The court shall not participate in any such discussions.

For the text of proposed Rule 11(c)(3), see infra note 59.

57. The proposed amendment does not change the range of alternative pleas in FED. R. CRIM. $\mathbf{P}$. 11(a). The "guilty for restitution" plea is technically a plea of guilty or nolo contendere. Its unique feature is the attachment of the agreement that the prosecutor will move under proposed Rule $11(c)(1)(B)$ for a binding condition that restitution will be the only consequence of the guilty plea to the particular count.

58. Consider a hypothetical situation in which the defendant has been indicted on three counts of mail fraud, each involving a different victim. Each count carries a maximum penalty of five years imprisonment and/or a $\$ 1000$ fine. 18 U.S.C. $\$ 1341$ (1982). Count 1 involves a fraud of \$1000; count 2,\$2500; and count 3,\$5000. Under the proposed rule, the defendant could plead guilty to count 1 with no agreement as to sentencing disposition and guilty to counts 2 and 3 with an agreement pursuant to proposed Rule $11(\mathrm{C})(1)(\mathrm{B})$ that the disposition of those counts will be limited to restitution. The effect of this agreement would be to leave the defendant exposed to a five-year prison term and $\$ 1000$ fine under count 1 and to the total restitutionary amount of $\$ 8500$ under all three counts. The defendant has gained a decrease in his exposure to punitive sanctions from 15 years and $\$ 3000$ to 5 years and $\$ 1000$. The government has gained a complete restitution order while retaining for the court the flexibility to impose a sentence with some punitive sanctions.

59. Rule 11(c) of the Federal Rules of Criminal Procedure should be amended by adding the following new subsection (3) and renumbering current subsections (3)-(6):

(3)(A) The court shall not accept an agreement requiring the dismissal of any charges without first inquiring of the attorney for the government in open court whether he has considered the defendant's possible liability to pay restitution arising from those charges.

(B) The court shall accept such an agreement only upon a finding stated on the record:

(i) that the charges to be dismissed do not give rise to any possible liability to pay restitution; or

(ii) that there is no factual basis for the charges to be dismissed; or

(iii) that a compelling reason exists which justifies dismissal of the charges despite the existence of a factual basis for them and possible restitutionary liability.associated with them.

If the court finds a compelling reason under subsection (iii) of this section, it shall state the reason or reasons on the record. 
state on the record that there is no factual basis for the charge, that the charge does not give rise to any restitutionary liability, or that a compelling reason requires dismissal of the charge in derogation of the victim's interest in restitution. ${ }^{80}$ For example, a court could dismiss a count only if successful prosecution of the count were unlikely because the victim or another witness is unable or unwilling to testify or if the victim's need for restitution had been satisfied by compensation through collateral proceedings. ${ }^{\circ 1}$ By excluding expediency from legitimate bases for dismissal of a charge, the use of restitution in plea bargaining would be harnessed to the sole purpose of broadening the scope of restitution orders.

This third amendment parallels the Act's requirement that the court state reasons on the record at the time of sentencing if it either does not order restitution or orders only partial restitution. ${ }^{62}$ But the proposed rule would be more effective than the statutory provision in increasing the use of restitution. It would give restitution priority before liability is determined rather than leaving consideration of restitution until it is too late to alter the outcome of the adjudicatory phase. Putting the court's required inquiry at this stage allows the court to direct the case from its early stages to ensure complete restitution.

The court would be aided in its inquiry under this proposed rule by a pre-pleading "Statement of Restitutionary Liability" from the prosecutor. $^{63}$ In this statement, the prosecutor would identify the victims of the

60. See supra note 59. This requirement would prevent the prosecutorial maneuvering that occurred in United States v. Orr, 691 F.2d 431 (9th Cir. 1982). In Orr, the prosecutor agreed with the defendant to file a superseding indictment which greatly reduced the victims' restitutionary recovery. But see Department of Justice, Implementation of Restitution Provisions of Victim-Witness Protection Act of 1982, at 8 (unpublished internal policy statement) (recommending pro-victim strategy of having defendant plead to superseding indictment which states his total restitutionary liability to all victims).

61. Compensation of the victim from another source can justify accepting a plea agreement only if the compensation amounts to restitution accomplished collaterally, that is, only if the compensation has come from the offender. This will occur, for example, in the rare case when a civil suit by the victim has proceeded to judgment before pleading in the criminal case or when the offender has settled his restitutionary obligations voluntarily.

The Act provides that restitution shall not be ordered if the victim has received compensation from another source, except that, "in the interest of justice," the court may order restitution to be paid to one who has compensated the victim. 18 U.S.C. $\$ 3579(e)(1)(1982)$. The Senate Report identifies such third parties as including "friends, family members, or other individuals and organizations . . . as well as insurance companies and state victim compensation programs." S. REP. No. 532, supra note 2, at 33, reprinted in 1982 U.S. CODE CONG. \& AD. NEws at 2539.

62. 18 U.S.C. $\$ 3579(\mathrm{a})(2)$ (1982). The required statement of reasons at the time of pleading does not supplant the statutorily required statement of reasons at the time of sentencing because reasons of a different sort may be applicable at the time of sentencing. At sentencing, the court must weigh considerations such as the ability of the offender to pay restitution in arriving at a final restitution order. 18 U.S.C. $\$ 3580$ (1982). The sentencing reasons thus may include those reasons of "practical necessity [for] limiting both the amount of restitution ordered and the period during which restitution payments are ordered to be made." S. REP. No. 532, supra note 2, at 32, reprinted in 1982 U.S. Code Cong. \& AD. NEws at 2538.

63. The following should be added as FED. R. CRIM. P. 11.1:

Rule 11.1. Statement of Restitutionary Liability 
alleged offense and estimate the extent of the injury to each in monetary terms. This information would be correlated to the indictment by count, but the estimates would be purely informational; it would not bind the prosecutor or the court in imposing restitution. The prosecutor would also identify the sources of this information and verify under oath that he has interviewed the victims and investigated their restitutionary needs. The requirement of this statement parallels the Act's requirement of a "Victim Impact Statement" from the probation department before sentencing. ${ }^{\text {o4 }}$

\section{B. The Roles of the Judge and Prosecutor}

Each of these revisions to the Federal Rules places on the judge an expanded duty to inform, inquire, or approve. Because the Act aims to bring restitution into the criminal process as a fundamental principle, responsibility for protecting that principle should be vested primarily in the judge-the symbolic center of the criminal justice system. In addition, there are practical reasons for stressing the role of the court. Expanded restitution will require advocacy of restitution as a principle as well as close monitoring of plea negotiations. The judge is better suited to these roles than is the prosecutor because she is not a direct participant in plea bargaining.

Significantly, the proposal does not create in the prosecutor a formal duty to be the victim's advocate. ${ }^{68}$ Still, the prosecutor will bear much of the burden of advancing the use of restitution. Vigorous advocacy of restitution by judges will require prosecutors to adapt their practices in charging and bargaining to yield negotiated results acceptable to the court. Early in the investigation, the prosecutor will have to determine the importance of each count in terms of restitution. ${ }^{68}$ When negotiating, the

(a) Before the time of pleading, the attorney for the government shall submit to the court and to the attorney for the defendant a statement containing a list of the victim or victims injured by the offense alleged in each count of the indictment and an estimate in monetary terms of the extent of the injury to each victim from each alleged offense.

(b) This statement shall include disclosure of the sources of the information contained in it.

(c) In this statement, the attorncy for the government shall affirm under oath that he has interviewed or reasonably attempted to interview each victim of the alleged offenses and that he has investigated diligently their restitutionary needs.

(d) Nothing in this statement shall limit any order of restitution or otherwise bind the court or the attorney for the government.

64. FED. R. CRIM. P. 32(c)(2).

65. For proposals that victims be given a formal role in criminal prosecutions, either through personal representatives or through the imposition of a duty on public prosecutors to represent their interests, see Goldstein, supra note 6, at 547-60.

66. See Department of Justice, Implementation of Restitution Provisions of Victim-Witness Protection Act of 1982, at 3 (unpublished internal policy statement) ("It is now even more important to identify all victims of a crime early in the investigative stage and to collect necessary information about their losses . . . ."). Under this Note's proposal, this investigation would have to culminate in the required "Statement of Restitutionary Liability." See supra note 63. 
prosecutor will have to avoid bargaining away restitutionary counts and determine, in light of the ultimate restitution order, how much punishment is appropriate. ${ }^{67}$ The position is one of partial discretion: the prosecutor retains his traditional authority with respect to punitive sanctions, but he must work under sharply limited discretion with respect to restitution.

\section{ConcLusion}

In the Act, Congress clearly articulated the popular will that the criminal process should serve the needs of victims. There is no need, however, to accomplish this reform at a high cost to the rights of defendants and to the integrity of the process. These proposals aim to transform the policy of the Act into a workable process. By relatively simple means-the extension of the "offense of conviction" principle and amendments to the Federal Rules of Criminal Procedure-this proposal serves the goals of the Act by striking the best balance between the rights of defendants and the needs of victims.

-Lawrence P. Fletcher

67. While it falls on the sentencing court to determine the actual sentence imposed, the prosecutor, early in the case, makes a similar judgment when he decides what will be the parameters of the government's bargaining position.

In addition to its rehabilitative and deterrent potential, see Schafer, supra note 12 , at 248-50, restitution has the virtue of neutralizing the offense in logical terms. The injury to the victim is "undone" by complete restitution, allowing the court to impose punitive sanctions focused more accurately on addressing the element of harm to society in the offense. 